\title{
Mineral Resources of the Farlin Creek Wilderness Study Area, Beaverhead County, Montana
}
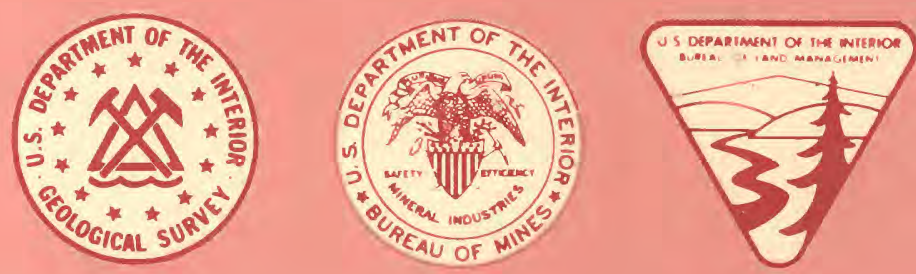

\section{U.S. GEOLOGICAL SURVEY BULLETIN 1724-C}

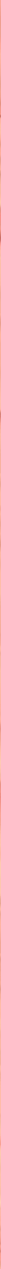



Chapter C
Mineral Resources of the Farlin Creek Wilderness Study Area, Beaverhead County, Montana

By ROBERT C. PEARSON, JERRY H. HASSEMER, WILLIAM F. HANNA, DONALD B. HOOVER, and HERBERT A. PIERCE

U.S. Geological Survey

STEVEN W. SCHMAUCH

U.S. Bureau of Mines

U.S. GEOLOGICAL SURVEY BULLETIN 1724

MINERAL RESOURCES OF WILDERNESS STUDY AREAS-

SOUTHWESTERN MONTANA 


\title{
DEPARTMENT OF THE INTERIOR \\ DONALD PAUL HODEL, Secretary
}

\author{
U.S. GEOLOGICAL SURVEY \\ Dallas L. Peck, Director
}

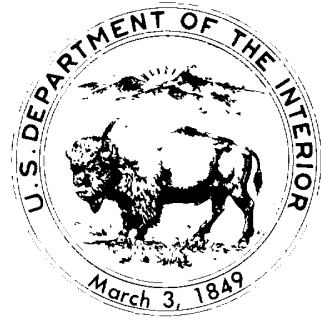

For sale by the

Books and Open-File Reports Section

U.S. Geological Survey

Federal Center

Box 25425

Denver, CO 80225

Library of Congress Cataloging-in-Publication Data

Mineral resources of the Farlin Creek Wilderness Study Area, Beaverhead County, Montana

(Mineral resources of wilderness study areas-southwestern Montana ;

ch. C)(U.S. Geological Survey bulletin ; 1724-C)

Bibliography: $p$.

Supt. of Docs. no.: I 19.3:1724-C

1. Mines and mineral resources-Montana-Farlin Creek Wilderness.

2. Farlin Creek Wilderness (Mont.) I. Pearson, Robert C. II. Series.

III. Series: U.S. Geological Survey bulletin ; 1724-C

QE75.B9 no. 1724-C $557.3 \mathrm{~s}$

[TN24.M9] [557.86'69]

$87-600161$ 


\section{STUDIES RELATED TO WILDERNESS}

\section{Bureau of Land Management Wilderness Study Areas}

The Federal Land Policy and Management Act (Public Law 94-579, October 21,1976) requires the U.S. Geological Survey and the U.S. Bureau of Mines to conduct mineral surveys on certain areas to determine the mineral values, if any, that may be present. Results must be made available to the public and be submitted to the President and the Congress. This report presents the results of a mineral survey of a part of the Farlin Creek (MT-076-034) Wilderness Study Area, Beaverhead County, Montana. 


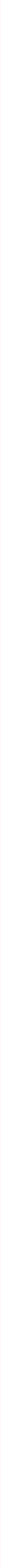




\section{CONTENTS}

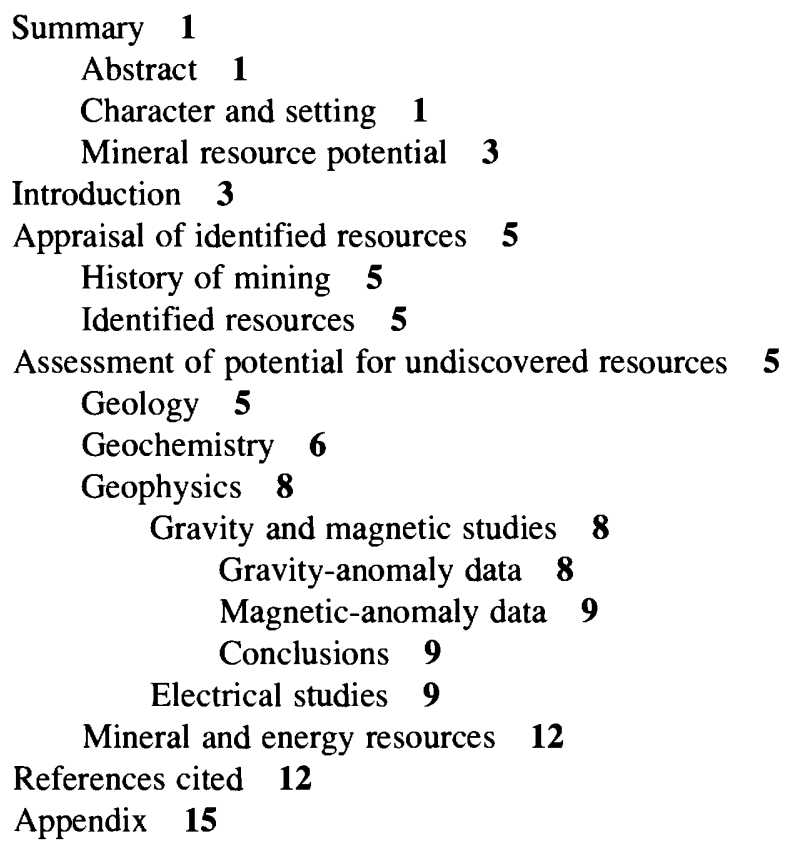

[Plate is in pocket]

1. Maps showing mineral resource potential, geology, geochemical sample localities, and geophysical data for the Farlin Creek Wilderness Study Area

\section{FIGURES}

1. Index map showing location of the Farlin Creek Wilderness Study Area and mining districts 2

2. Mineral resource potential map of the Farlin Creek Wilderness Study Area 4

3. Total-intensity ground and aeromagnetic profiles, Farlin Creek Wilderness Study Area and vicinity 10

4. Graphs showing telluric voltage along telluric traverses and resistivities at AMT (audio-magnetotelluric) stations, Farlin Creek Wilderness Study Area 11

\section{TABLES}

1. Prospects in and adjacent to the Farlin Creek Wilderness Study Area 6

2. Analyses of stream-sediment and rock samples, Farlin Creek Wilderness Study Area 7

3. Magnetization and density of rock samples, Farlin Creek Wilderness Study Area 8 


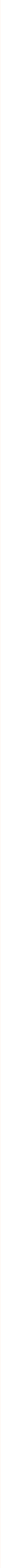




\title{
Mineral Resources of the Farlin Creek Wilderness Study Area, Beaverhead County, Montana
}

\author{
By Robert C. Pearson, Jerry H. Hassemer, William F. Hanna, \\ Donald B. Hoover, and Herbert A. Pierce \\ U.S. Geological Survey
}

Steven W. Schmauch

U.S. Bureau of Mines

\section{SUMMARY}

Abstract

The Farlin Creek Wilderness Study Area (MT-076034) is in the south-central Pioneer Mountains about 24 miles west-northwest of Dillon, Beaverhead County, southwestern Montana (fig. 1). At the request of the U.S. Bureau of Land Management, an area of 610 acres (less than 1 square mile) was investigated by the U.S. Geological Survey and the U.S. Bureau of Mines in 1984. The area contains no mines or prospects, no visible evidence of mineralization, and no identified mineral resources. Geophysical evidence suggests that three parts of the area have moderate mineral resource potential for undiscovered resources of molybdenum. The entire area has a low resource potential for all other metals and for all nonmetals, fuels, and geothermal energy.

\section{Character and Setting}

The Farlin Creek area is in the foothills of the Pioneer Mountains at an average elevation of about 7,000 ft (feet). Farlin Creek flows through the area, and Steel Creek drains a small part along the south edge. These small perennial streams flow west into Grasshopper Creek, a south-flowing trunk stream that occupies a broad flat valley less than $2 \mathrm{mi}$ (miles) west of the area. The area is largely forested by Douglas fir, but the lower south-facing slopes are covered by sage and grasses. Rutted and gullied logging and mine roads provide vehi- cle access across private land from the maintained road in Grasshopper Creek valley.

The Pioneer Mountains are made up mostly of Proterozoic, Paleozoic, and Mesozoic sedimentary rocks that have been intruded by Late Cretaceous and early Tertiary igneous rocks; minor sedimentary and volcanic rocks of Tertiary age are also present (see geologic time chart in the appendix). A northerly trending belt of thrust faults passes through the Pioneer Mountains. Evidence for thrust faulting has been noted in most preTertiary sedimentary rocks, and Proterozoic rocks everywhere in the range are probably parts of thrust plates. Steep faults are also common, cutting igneous as well as sedimentary rocks.

Bedrock in the Farlin Creek area is chiefly a fairly uniform, light-gray granodiorite of Cretaceous age, part of a protrusion from the Pioneer batholith, a large body that forms the high central part of the eastern Pioneer Mountains and extends across the western Pioneer Mountains as well. The granodiorite is rather friable and weathers to low rounded outcrops and to thick granular soil consisting of small rock fragments and fairly fresh grains of quartz, feldspars, biotite, and hornblende. Other intrusive igneous rocks, slightly older than the granodiorite but also of Cretaceous age, are present near the study area. The only other bedrock within the area is Proterozoic quartzite, which underlies a small area along the north edge and is intruded by granodiorite. Similar quartzite is widespread in the rest of the Pioneer Mountains. Near the granodiorite, the quartzite typically contains small light to dark dikes related to the granodiorite and has been partially recrystallized. As a result of this heating, new muscovite, biotite, and chlorite have formed in the quartzite. 


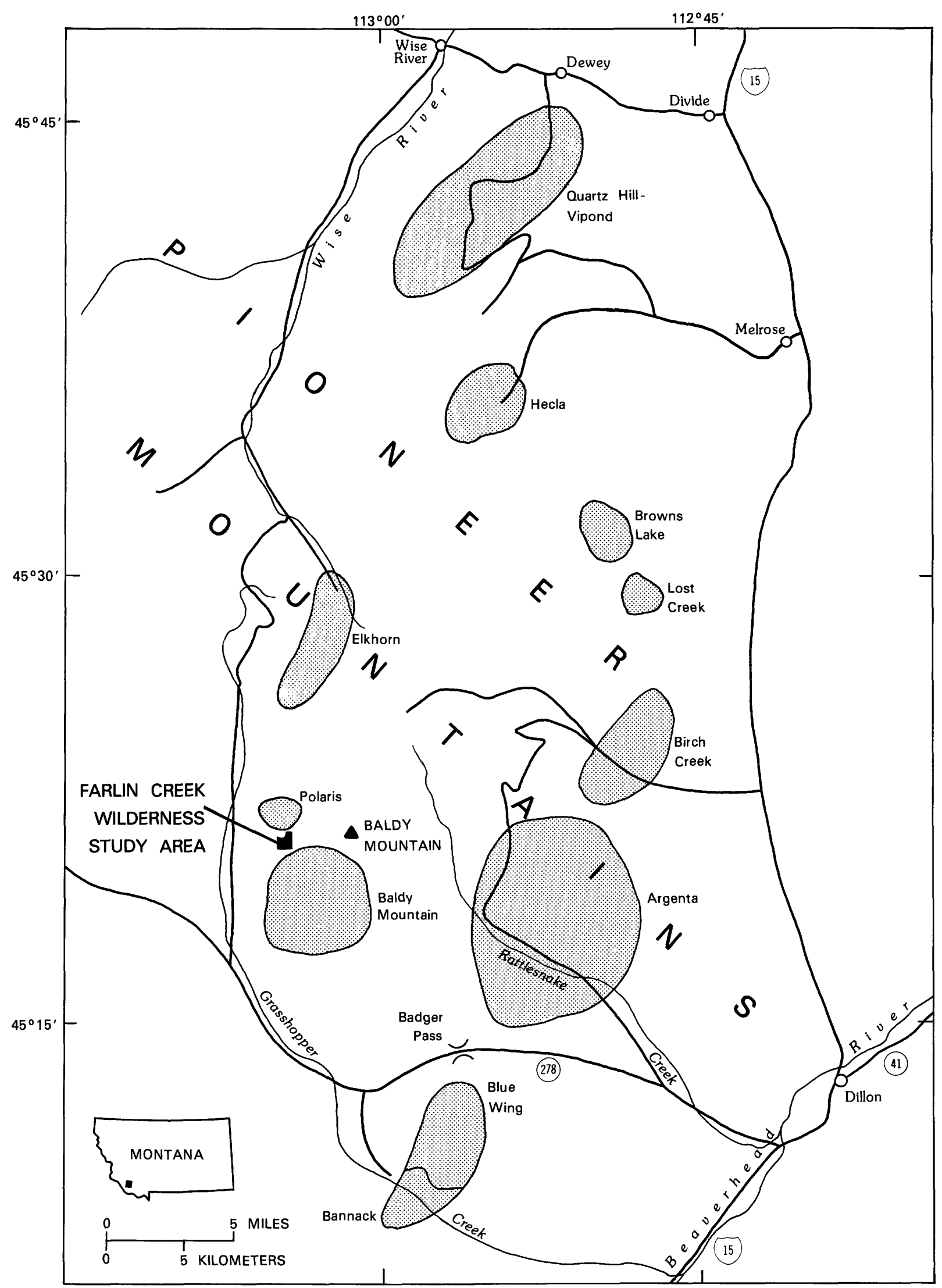

Figure 1. Index map showing location of the Farlin Creek Wilderness Study Area and mining districts (shaded areas) in eastern Pioneer Mountains, Beaverhead County, Mont. 
Surficial deposits include a block stream in the east-central part of the study area and minor amounts of reworked granitic debris along the $V$-shaped stream valleys. The block stream consists dominantly of blocks of quartzite that moved as a mass down Farlin Creek from the southwest flank of Baldy Mountain, about $1 \mathrm{mi}$ to the east.

No evidence of faulting was found within the Farlin Creek area; however, the Proterozoic quartzite is interpreted to be part of the upper plate of a thrust fault. In the vicinity of the study area, the base of the thrust plate is speculated to lie at a depth of hundreds or perhaps thousands of feet.

Numerous small to moderate-sized mining districts are in the Pioneer Mountains. The Farlin Creek area lies between two of these: the Polaris district, $0.5 \mathrm{mi}$ to the north, and the Baldy Mountain district, 1-4 mi to the southeast. In these districts, gold and silver have been mined from veins in carbonate rocks; the absence of these favorable rocks from the Farlin Creek area indicates that deposits of this type are not likely to occur there.

\section{Mineral Resource Potential}

No identified mineral resources are in the area, nor has direct evidence of mineralization been found. Electrical, magnetic, and gravity geophysical data are interpreted to suggest that altered rocks occur at depth in three places, but this interpretation is not supported by any other evidence despite the availability of rather complete geological, geochemical, and geophysical data. The mineral resource potential of the areas of these geophysical anomalies is moderate for resources of molybdenum (fig. 2). The potential of the rest of the area for all metals and of the entire area for nonmetals, fuels, and geothermal energy is low.

\section{INTRODUCTION}

The Farlin Creek Wilderness Study Area (MT-076034) is in the south-central Pioneer Mountains in Beaverhead County, southwestern Montana (fig. 1). It is 24 mi west-northwest of the city of Dillon. At the request of the U.S. Bureau of Land Management (BLM), the U.S. Geological Survey (USGS) and the U.S. Bureau of Mines (USBM) studied 610 acres of the Farlin Creek Wilderness Study Area. In this report the studied area is called the "wilderness study area" or simply the "study area." The area consists of most of sec. 4, T. $6 \mathrm{~S}$., R. 12 W., and SW $1 / 4$ sec. 34, T. 5 S., R. 12 W. (pl. 1). Beaverhead National Forest is contiguous on the north, east, and south sides, and private land and other BLM land is contiguous on the west side. Typical of moderate slopes at intermediate elevations $(6,800-7,700 \mathrm{ft})$ in this region, the area is mostly covered by Douglas fir forest. Farlin Creek flows through the area, draining most of it, and Steel Creek drains a small area along the south edge. Both Farlin and Steel Creeks are small perennial streams tributary to Grasshopper Creek to the west. At the head of Farlin Creek, 2 mi to the east, Baldy Mountain rises above timberline to $10,568 \mathrm{ft}$. Vehicular access from the maintained gravel road along Grasshopper Creek is limited because the old logging and mining roads that approach the area cross private land and are in disrepair.

The USBM searched Beaverhead County records for evidence of mining claim staking, traversed the area in search of mines and prospects, mapped and sampled prospects, and collected and panned samples of alluvium from streams. The USGS revised part of an existing geologic map (Pearson and Zen, 1985), conducted a gravity survey that augmented data from a previous survey (Kaufmann and others, 1983), made ground magnetic traverses that were used in conjunction with an earlier aeromagnetic survey (U.S. Geological Survey, 1979), and made electrical studies using telluric and audio-magnetotelluric techniques. Both agencies collected rock and pannedconcentrate samples for analysis, and analytical data from a previous stream-sediment geochemical survey were used. The study area also had been studied previously as part of the eastern Pioneer Mountains (Pearson and others, 1983) but was not specifically discussed in that report. Because the area is very small, its geology simple, and its mineral resource potential low or moderate, no companion reports on geology, geochemistry, aeromagnetics, or gravity are planned. Results of the electrical surveys are described in greater detail by Hoover and Pierce (1985). Results of USBM investigations were previously released (Schmauch, 1985).

This report presents an evaluation of the mineral endowment (identified resources and mineral resource potential) of the study area and is the product of several separate studies by the USBM and the USGS in 1984. Identified resources are classified according to the system of the USBM and USGS (1980), which is shown in the appendix of this report. Identified resources are studied by the USBM. Mineral resource potential is the likelihood of occurrence of undiscovered metals and nonmetals, industrial rocks and minerals, and of undiscovered energy sources (coal, oil, gas, oil shale, and geothermal sources). Potential is classified according to the system of Goudarzi (1984), which is shown in the appendix. Undiscovered resources are studied by the USGS.

The assistance of the Montana Bureau of Mines and Geology and of the BLM, Dillon, Mont., is acknowledged. John R. Benham assisted in the USBM field investigations. 


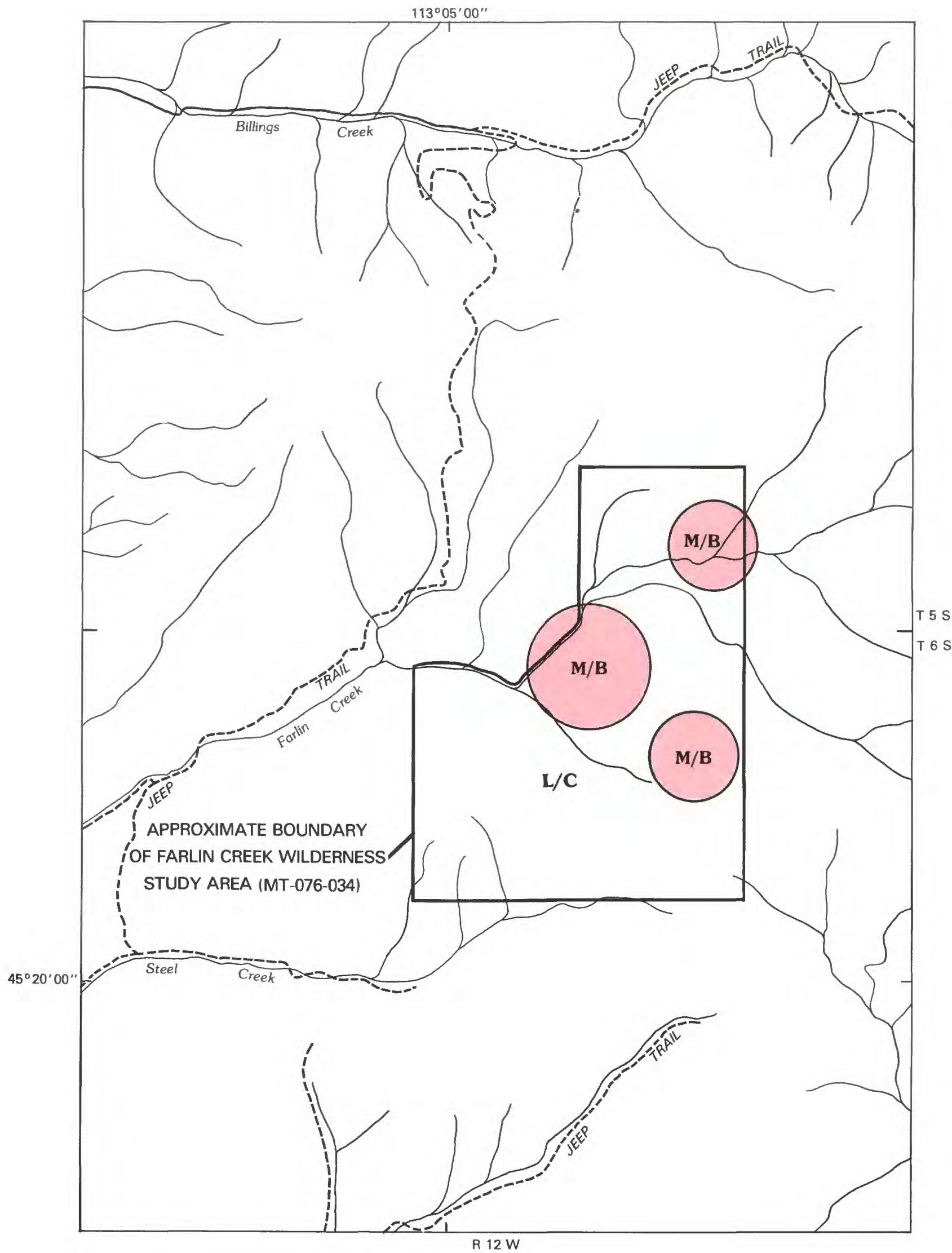

Figure 2 (above and facing page). Mineral resource potential map of the Farlin Creek Wilderness Study Area, Beaverhead County, Mont. 


\section{EXPLANATION OF MINERAL RESOURCE POTENTIAL}

[See definitions in appendix]

M/B Geologic terrane having moderate resource potential for molybdenum, with certainty level $B$, and low resource potential for other metals, monmetals, oil and gas, and geothermal energy, with certainty level C

L/C Geologic terrane having low resource potential for all metals, nonmetals, oil and gas, and geothermal energy, with certainty level C

\section{APPRAISAL OF IDENTIFIED RESOURCES}

\section{By Steven W. Schmauch U.S. Bureau of Mines}

\section{History of Mining}

Placer gold was discovered along Dyce and Steel Creeks during the 1860's (Corey, 1933, p. 25), and lodes were discovered soon after in the drainage basins of Scudder, Dyce, and Taylor Creeks, an area southeast of the study area that became known as the Baldy Mountain mining district (Geach, 1972, p. 69). Records of mining in the Baldy Mountain district are sparse, but apparently the ore bodies were snall and mining essentially ceased before 1900. In the 1950's, tungsten was discovered in the Baldy Mountain district, and a mill was built in 1955 to process the ore; however, no record of tungsten production is known. Total recorded production since records have been kept beginning in 1902 is $348 \mathrm{oz}$ (troy ounces) gold, 3,418 oz silver, 4,986 lbs (pounds) copper, 80,901 lbs lead, and 6,700 lbs zinc (Geach, 1972, p. 69). The Polaris mining district, about $0.5 \mathrm{mi}$ north of the study area, consists of only one notable mine, the Polaris, which was discovered in 1883 and which has produced at least some ore in most years since. Geach $(1972$, p. 121) lists production from the Polaris mine from 1902 through 1965 as $312 \mathrm{oz}$ gold, $120,023 \mathrm{oz}$ silver, 20,937 lbs copper, $11,140 \mathrm{lbs}$ lead, and $12,100 \mathrm{lbs}$ zinc. Mining in the Polaris was almost continuous during the 1960's and 1970's, but the mine closed in 1983.

\section{Identified Resources}

A large group of contiguous mining claims was located in 1983 from the Polaris district southward into the northernmost part of the study area. Parts of four of these claims are in the study area, and the location of trenches on them are shown on map A (pl. 1). The trenches and the results of analysis of samples collected from them are described in table 1. Rock samples were checked for radioactivity and fluorescence and analyzed by fire assay, atomic absorption, or inductively coupled argon plasma spectrophotometry. Some samples were analyzed by semiquantitative emission spectroscopy for 43 elements. Three samples of alluvium from Farlin and Steel Creeks were panned. Analysis of the concentrates indicates that two of these samples contain very fine grained gold worth $\$ 0.03$ and $\$ 0.10$ per cubic yard (calculated at $\$ 400$ per $\mathrm{oz})$. The low values indicate that no resource of placer gold is present in the area, nor were any other mineral resources identified during the USBM studies.

\section{ASSESSMENT OF POTENTIAL FOR UNDISCOVERED RESOURCES}

\author{
By Robert C. Pearson, Jerry H. Hassemer, \\ William F. Hanna, Donald B. Hoover, and \\ Herbert A. Pierce \\ U.S. Geological Survey
}

\section{Geology}

The Pioneer Mountains are a subcircular mountain mass formed mainly of Proterozoic, Paleozoic, and Mesozoic sedimentary rocks that have been intruded by many large and small bodies of Late Cretaceous and early Tertiary igneous rocks (Pearson and Zen, 1985). Minor amounts of Tertiary sedimentary and volcanic rocks are also present within the range as well as in basins surrounding it. The range is within a belt of thrust faults, and in many places the pre-Tertiary sedimentary rocks exposed among the plutons are complexly folded and show evidence of being moved laterally along thrust faults. Vertical movement on steep faults has affected some Tertiary rocks as well as the older rocks. The eastern half of the Pioneer Mountains is mainly a single body of intrusive igneous rock called Uphill Creek Granodiorite of Cretaceous age.

The oldest rocks in the study area are Middle Proterozoic quartzite, which does not crop out but is inferred on the basis of float to be present in a narrow strip along the north boundary (pl. 1). These rocks, which were intruded by the granodiorite, are tentatively assigned to the Mount Shields Formation of the Missoula Group on the basis of their similarity in lithology and bedding characteristics to rocks of this formation to the north of 
Table 1. Prospects in and adjacent to the Farlin Creek Wilderness Study Area, Beaverhead County, Mont.

[Underlined names indicate properties inside the study area]

\begin{tabular}{|c|c|c|c|c|}
\hline $\begin{array}{l}\text { No. on } \\
\text { plate } 1\end{array}$ & Name & Summary & Workings & Sample data \\
\hline BM1 & $\frac{\text { Polaris }}{\text { No. } 40}$ & $\begin{array}{l}\text { Predominant rock is quartzite, with } \\
10 \text { percent granodiorite float. }\end{array}$ & $\begin{array}{l}\text { One } 20-f t-1 \text { ong } \\
\text { trench. }\end{array}$ & $\begin{array}{l}\text { One random grab sample of quartzite } \\
\text { and granodiorite contained no } \\
\text { significant values. }\end{array}$ \\
\hline BM2 & $\frac{\text { Polaris }}{\text { No. } 17}$ & $\begin{array}{l}\text { Decomposed, medium-grained granodio- } \\
\text { rite and a minor amount of quartz- }\end{array}$ & $\begin{array}{l}\text { Une } 30-\mathrm{ft}-1 \text { ong } \\
\text { trench. }\end{array}$ & $\begin{array}{l}\text { One chip sample contained no } \\
\text { significant values. }\end{array}$ \\
\hline BM3 & $\frac{\text { Polaris }}{\text { No. } 7 .}$ & $\begin{array}{l}\text { Float consists of } 95 \text { percent quartz- } \\
\text { ite and } 5 \text { percent granodiorite. }\end{array}$ & $\begin{array}{l}\text { One } 22-\mathrm{ft} \text {-long } \\
\text { trench. }\end{array}$ & $\begin{array}{l}\text { One random grab sample of quartzite } \\
\text { and granodiorite contained no } \\
\text { significant values. }\end{array}$ \\
\hline BM4 & $\frac{\text { Polaris }}{\text { No. } 15}$ & $\begin{array}{l}\text { Float consists of decomposed grano- } \\
\text { diorite. }\end{array}$ & $\begin{array}{l}\text { One } 22-f \text { t-long } \\
\text { trench. }\end{array}$ & $\begin{array}{l}\text { One random grab sample contained no } \\
\text { significant values. }\end{array}$ \\
\hline BM5 & Unknown $^{1}$ & Quartzite and granodiorite float. & One pit-- - - & $\begin{array}{l}\text { One random grab sample of quartzite } \\
\text { and granodiorite contained no } \\
\text { significant values. }\end{array}$ \\
\hline BM6 & $\begin{array}{l}\text { Steel Creek } \\
\text { adit. }\end{array}$ & $\begin{array}{l}\text { A } 2-\text { to } 4 \text {-ft-thick iron-oxide-stained, } \\
3.0 \mathrm{ft} \text { thick gouge-filled shear } \\
\text { zone trends east and dips } 55^{\circ} \mathrm{S} \text {. } \\
\text { in medium-grained granodiorite. }\end{array}$ & $\begin{array}{l}\text { One pit and an } \\
\text { inclined adit. }\end{array}$ & $\begin{array}{l}\text { Three chip samples across the shear } \\
\text { zone contained no significant } \\
\text { values. }\end{array}$ \\
\hline
\end{tabular}

${ }^{1}$ Could not be identified by claim notices or through published or unpublished reports.

the batholith in the Wise River valley (fig. 1). The rocks are mostly thick- to thin-bedded, coarse- and mediumgrained, variably micaceous and feldspathic quartzite and minor quartzose phyllite. Biotite, muscovite, and chlorite are common within the quartzite and on fractures, presumably as a result of metamorphism by the granodiorite. The contact of quartzite with granodiorite is obscure because of numerous small dikes that intrude the contact zone.

The study area is underlain almost entirely by Uphill Creek Granodiorite (pl. 1). The granodiorite in the area is part of a westward protrusion near the south end of the Pioneer batholith (Pearson and Zen, 1985). On the north and west sides of the protrusion, the granodiorite intrudes Proterozoic quartzite; on the southwest and south sides, it intrudes older intrusive rocks, mainly biotitepyroxene granodiorite and hornblende gabbro, and at one place it probably intrudes Jefferson Dolomite (Devonian). Uphill Creek Granodiorite is light gray, medium grained, and nonfoliated, and it contains several percent each of hornblende and biotite. Within the study area, the rock appears to be fairly uniform in composition and texture. It weathers into rounded outcrops and a loose aggregate of mineral grains. Further description of the rock is given by Snee $(1978,1982)$. The contact of the granodiorite with Proterozoic quartzite along the north boundary of the area is poorly exposed, but elsewhere near the study area it is commonly a gradational zone as much as a few hundred feet wide, consisting of small light- and dark-colored dikes and minor tourmaline-bearing quartz veins in partially recrystallized and fractured micaceous quartzite.

The lobate block stream in the eastern part of the study area is composed of boulder-sized angular to subrounded fragments of Proterozoic quartzite and minor granodiorite that were derived from the southwest flank of Baldy Mountain. The deposit occupies tributary valleys of Farlin Creek and is at least $100 \mathrm{ft}$ thick in places. It is probably a periglacial deposit that formed in the Pleistocene.

Geologic mapping in the surrounding region (Pearson and Zen, 1985) has shown the Proterozoic quartzite to be part of the upper plate of a major thrust fault. The lower plate, if present near the Farlin Creek area, is probably composed in part or wholly of Paleozoic carbonate rocks, which are the most favorable host rocks for ore deposits in the mining districts of the eastern Pioneer Mountains. Beneath the Farlin Creek area, however, these carbonate rocks may not be present at all because of intrusion of the Pioneer batholith; and even if they are present, they are probably very deeply buried.

\section{Geochemistry}

Four rock samples (84P004-84P007) collected by the USGS are located on map A (pl. 1), and the analyses are given in table 2 . The rock samples contained no elements in unusually large amounts. 
Table 2. Analyses of stream-sediment and rock samples, Farlin Creek Wilderness Study Area, Beaverhead County, Mont.

[See plate 1 for sample localities. Samples 84P004-84P007 are rock samples; others are stream-sediment samples. All values are parts per million except $\mathrm{Fe}, \mathrm{Mg}, \mathrm{Ca}$, and $\mathrm{Ti}$, which are in percent. N, element was not found and is less than amount shown in parentheses; L, element was detected but was less than amount shown in parentheses; ..., not determined; G, greater than amount shown in parentheses. The following elements were not detected in any sample (lower limit of analytical determination in parentheses): $\mathrm{Ag}(0.5), \mathrm{Au}(10), \mathrm{Bi}(10), \mathrm{Cd}(20)$, and Sn (10). All analyses by semiquantitative spectrographic analysis except Au (0.1) (samples 84P004-84P007), Zn, and Sb, which were determined by atomic absorption (AA), and As, which was determined by a wet-chemical technique (CM). Analyses of samples 8FH3141-8FH3195 from Breit (1980). Spectrographic analyses of samples 84P004-84P007 are reported to the nearest number in the series 100, 70, 50, 30, 20, 15, 10 , and so on, which represent approximate midpoints of grouped data on a geometric scale. Analysts of samples 84P004-84P007: P. H. Briggs, N. Conklin, and J. G. Crock]

\begin{tabular}{|c|c|c|c|c|c|c|c|c|c|c|c|c|c|c|c|c|}
\hline $\begin{array}{c}\text { Sample } \\
\text { No. }\end{array}$ & $c^{\text {Lat }}$ & $=(N)$ & & ong (W) & & $\mathrm{Fe}$ & $\mathrm{Mg}$ & $\mathrm{Ca}$ & $\mathrm{Ti}$ & \multicolumn{2}{|c|}{$\mathrm{Mn}$} & B & $\mathrm{Ba}$ & Be & Co & $\mathrm{Cr}$ \\
\hline $8 \mathrm{FH} 3141$ & 45 & 2054 & 113 & $\begin{array}{lll}3 & 04 & 44\end{array}$ & & 7 & 0.7 & 1 & 0. & \multicolumn{2}{|c|}{1,000} & 20 & 500 & 1 & 15 & 100 \\
\hline $8 \mathrm{FH} 3145$ & 45 & $20 \quad 46$ & 113 & $\begin{array}{lll}3 & 05 & 02\end{array}$ & & 10 & 1 & 1 & • & \multicolumn{2}{|c|}{1,000} & 20 & 500 & 1 & 20 & 150 \\
\hline $8 \mathrm{FH} 3150$ & 45 & 2048 & 113 & $\begin{array}{lll}3 & 05 & 17\end{array}$ & & 10 & 1 & 1.5 & - & \multicolumn{2}{|c|}{1,000} & 20 & 300 & 1 & 20 & 150 \\
\hline $8 \mathrm{FH} 3175$ & 45 & 2055 & 113 & $\begin{array}{lll}3 & 05 & 27\end{array}$ & & 7 & 1 & 1 & - & \multicolumn{2}{|c|}{1,000} & 50 & 500 & 1 & 20 & 150 \\
\hline $8 \mathrm{FH} 3181$ & 45 & 2049 & 113 & $\begin{array}{lll}3 & 05 & 29\end{array}$ & & 10 & 1 & 1.5 & • & \multicolumn{2}{|c|}{1,000} & 20 & 500 & 1 & 20 & 200 \\
\hline $8 \mathrm{FH} 3183$ & 45 & 2040 & 113 & $305 \quad 46$ & & 15 & .7 & 1 & • & \multicolumn{2}{|c|}{1,000} & 10 & 300 & 1 & 30 & 300 \\
\hline $8 \mathrm{FH} 3187$ & 45 & 2037 & 113 & $\begin{array}{lll}3 & 06 & 05\end{array}$ & & 15 & .7 & 1.5 & • & \multicolumn{2}{|c|}{1,000} & 20 & 500 & 1 & 20 & 200 \\
\hline $8 \mathrm{FH} 3191$ & 45 & 2033 & 113 & $\begin{array}{lll}3 & 06 & 12\end{array}$ & & 20 & .7 & 1 & & \multicolumn{2}{|c|}{1,000} & 20 & 300 & 1 & 30 & 300 \\
\hline $8 \mathrm{FH} 3195$ & 45 & 2028 & 113 & $\begin{array}{lll}3 & 06 & 27\end{array}$ & & 10 & 1 & 1.5 & - & 1,0 & & 20 & 700 & & 20 & 100 \\
\hline 84P004 & 45 & $20 \quad 57$ & 113 & $\begin{array}{lll}3 & 05 & 13\end{array}$ & & 3 & 1.5 & 1.5 & . & & 0 & 30 & 3,000 & .5 & 10 & 15 \\
\hline $84 \mathrm{P} 005$ & 45 & 2122 & 113 & 30456 & & 2 & 1.5 & .15 & - & & 0 & 30 & 1,500 & .5 & 10 & 30 \\
\hline $84 \mathrm{P} 006$ & 45 & 2112 & 113 & $304 \quad 35$ & & 3 & 1.5 & 3 & . & & 0 & $N(10)$ & 1,500 & .5 & 15 & 10 \\
\hline $84 \mathrm{P} 007$ & 45 & 2116 & 113 & $304 \quad 54$ & & 5 & 2 & 5 & . & & 0 & $N(10)$ & 1,500 & .5 & 15 & 30 \\
\hline $\begin{array}{l}\text { Sample } \\
\text { No. }\end{array}$ & $\mathrm{Cu}$ & $\mathrm{La}$ & Mo & $\mathrm{Nb}$ & $\mathrm{Ni}$ & $\mathrm{Pb}$ & $\mathrm{Sc}$ & $\mathrm{Sr}$ & V & W & $\mathrm{Y}$ & $\mathrm{Zr}$ & Th & $\begin{array}{c}\mathrm{Zn} \\
(\mathrm{AA})\end{array}$ & $\begin{array}{c}\mathrm{Sb} \\
(\mathrm{AA})\end{array}$ & $\begin{array}{l}\text { As } \\
\text { (CM) }\end{array}$ \\
\hline $8 \mathrm{FH} 3141$ & 20 & 200 & 15 & 30 & 10 & 20 & 20 & 300 & 200 & $N(50)$ & 100 & $G(1,000)$ & 100 & 35 & $\mathrm{~L}(1)$ & $L(10)$ \\
\hline $8 \mathrm{FH} 3145$ & 20 & 200 & $N(5)$ & 20 & 15 & 20 & 20 & 300 & 500 & $N(50)$ & 100 & $G(1,000)$ & $L(100)$ & 45 & $N(1)$ & $\mathrm{L}(10)$ \\
\hline $8 \mathrm{FH} 3150$ & 30 & 200 & $N(5)$ & 20 & 15 & 20 & 20 & 300 & 500 & $N(50)$ & 100 & $G(1,000)$ & $\mathrm{L}$ & 40 & $\mathrm{~L}(1)$ & $L(10)$ \\
\hline $8 \mathrm{FH} 3175$ & 30 & 150 & 7 & 20 & 20 & 20 & 20 & 200 & 300 & $N(50)$ & 100 & 1,000 & 100 & 45 & $\mathrm{~L}(1)$ & $L(10)$ \\
\hline $8 \mathrm{FH} 3181$ & 30 & 200 & $N(5)$ & 20 & 10 & 30 & 20 & 300 & 500 & $N(50)$ & 100 & 700 & $L(100)$ & 50 & $L(1)$ & $\mathrm{L}(10)$ \\
\hline $8 \mathrm{FH} 3183$ & 30 & 200 & $N(5)$ & 20 & 20 & 20 & 20 & 200 & 700 & $N(50)$ & 150 & $G(1,000)$ & 100 & 45 & $\mathrm{~L}(1)$ & $L(10)$ \\
\hline $8 \mathrm{FH} 3187$ & 30 & 150 & 10 & 20 & 20 & 20 & 20 & 300 & 500 & 50 & 100 & 1,000 & $N(100)$ & 45 & $\mathrm{~L}(1)$ & $L(10)$ \\
\hline $8 \mathrm{FH} 3191$ & 30 & 200 & $N(5)$ & 30 & 20 & 15 & 20 & 300 & 700 & $N(50)$ & 150 & 1,000 & $N(100)$ & 45 & $L(1)$ & $\mathrm{L}(10)$ \\
\hline 8 FH3195 & 20 & 100 & 5 & 20 & 15 & 30 & 20 & 300 & 300 & $N(50)$ & 70 & 500 & $\mathrm{~N}(100)$ & 45 & $\mathrm{~L}(1)$ & 10 \\
\hline $84 \mathrm{P} 004$ & $N(5)$ & 150 & $N(5)$ & $N(20)$ & 15 & 15 & 15 & 1,000 & 150 & $N(50)$ & 50 & 150 & -- & --- & -- & -- \\
\hline $84 \mathrm{P} 005$ & $N(5)$ & 70 & $N(5)$ & 20 & 20 & 15 & 10 & 70 & 70 & $N(50)$ & 50 & 300 & -- & -- & --- & -- \\
\hline $84 \mathrm{P} 006$ & 7 & 70 & $N(5)$ & $N(20)$ & 7 & 20 & 10 & 700 & 100 & $N(50)$ & 30 & 200 & -- & --- & --- & --- \\
\hline $84 \mathrm{P} 007$ & 50 & 70 & $N(5)$ & $\mathrm{N}(20)$ & 30 & 20 & 20 & 700 & 150 & $N(50)$ & 50 & 200 & --- & -- & -- & --- \\
\hline
\end{tabular}

Stream-sediment samples were collected from Farlin Creek in 1979 by George Breit of the USGS. These samples were collected in connection with a detailed geochemical study of the Polaris district (Breit, 1980) and were also utilized in the mineral resource appraisal of the eastern Pioneer Mountains (Pearson and others, 1983). Five of the samples (8FH3181-8FH3195) were collected from Farlin Creek downstream from (west of) the study area, and one (8FH3175) was from a northern tributary of Farlin Creek, also west of the area. The remaining three samples (8FH3141-8FH3150) were from Farlin Creek along the northwest boundary of the study area. Sample localities are shown on map A (pl. 1), and analytical data are given in table 2 .

Except for a few elements in a few samples, the analytical data are generally at background levels. No gold or silver was detected in any of the USGS samples. Small amounts (5-15 ppm (parts per million)) of molyb- 
denum were detected in four stream-sediment samples; one of these also contained $50 \mathrm{ppm}$ tungsten, and another, $10 \mathrm{ppm}$ arsenic. Of these four samples, only one, sample 8FH3141, was from within the study area; it contained $15 \mathrm{ppm}$ molybdenum and no other elements of apparent significance. The next three samples downstream from 8FH3141 did not contain detectable molybdenum.

The only mineralized rocks known in the Farlin Creek drainage basin that are likely sources of the molybdenum, tungsten, and arsenic detected in the stream sediments are (1) west of the study area at the head of the northern tributary mentioned above, which contains several small mines and prospects in the southern part of the Polaris district, and (2) east of the study area at the head of Farlin Creek at elevations of 9,000-9,700 ft on the southwest flank of Baldy Mountain (fig. 1), where quartz veins have been prospected and possibly mined. However, the amounts of these elements in the streamsediment samples are low-at the lower limit of detection, except for molybdenum-and the anomalous samples are interspersed along the stream with samples that are not anomalous, both factors suggesting small local sources that, in the absence of other encouraging information, are not regarded as favorable indications for the presence of mineral resources in the study area.

\section{Geophysics}

\section{Gravity and Magnetic Studies}

Gravity- and magnetic-anomaly data for the Farlin Creek Wilderness Study Area principally reflect occurrences and lateral boundaries of plutonic rocks and of valley fill. Supplementary magnetization and density measurements of Proterozoic quartzite, Paleozoic carbonate, and Cretaceous Uphill Creek Granodiorite (table 3) from within or near the study area indicate that the plutonic rocks are much more strongly magnetic but of about the same density as the quartzite and carbonate rocks.

\section{Gravity-Anomaly Data}

A gravity survey conducted by J. H. Hassemer using a LaCoste and Romberg ${ }^{1}$ geodetic gravimeter and consisting of 40 measurements was combined with 13 gravity measurements from Kaufmann and others (1983) made with the same type of gravimeter. The combined gravity data were reduced to Bouguer gravity anomalies by standard procedures, as summarized by Cordell and others (1982).

\footnotetext{
'Any use of trade names is for descriptive purposes only and does not imply endorsement by the U.S. Geological Survey.
}

Table 3. Magnetization and density of rock samples, Farlin Creek Wilderness Study Area, Beaverhead County, Mont.

[K, apparent magnetic susceptibility; Rem J, magnitude of remanent magnetization; Total $\mathbf{J}$, magnitude of vector sum of induced and remanent magnetization; computed using directional data of remanent magnetization not shown. Susceptibilities in emu/ $\mathrm{cm}^{3}$ (electromagnetic units per cubic centimeter) may be converted to dimensionless SI (International System) units by multiplying by $4 \pi$; magnetization in $\mathrm{emu} / \mathrm{cm}^{3}$ may be converted to SI units of $\mathrm{A} / \mathrm{m}$ (amperes per meter) by multiplying by $10^{3} ; \mathrm{g} / \mathrm{cm}^{3}$, grams per cubic centimeter; n.d., not determined]

\begin{tabular}{|c|c|c|c|c|c|c|}
\hline \multirow{2}{*}{$\begin{array}{l}\text { Sample } \\
\text { No. on } \\
\text { map }\end{array}$} & \multirow{2}{*}{$\begin{array}{c}\text { Map } \\
\text { unit } \\
\text { symbol }\end{array}$} & \multirow{2}{*}{$\frac{10^{-5} \mathrm{emu}}{\mathrm{cm}^{3}}$} & \multirow{2}{*}{$\begin{array}{l}\text { Rem. J } \\
\frac{10^{-5} \mathrm{emu}}{\mathrm{cm}^{3}}\end{array}$} & \multirow{2}{*}{$\begin{array}{l}\text { Total J } \\
\frac{10^{-5} \mathrm{emu}}{\mathrm{cm}^{3}}\end{array}$} & \multicolumn{2}{|c|}{$\begin{array}{l}\text { Bulk density } \\
\left(\mathrm{g} / \mathrm{cm}^{3}\right)\end{array}$} \\
\hline & & & & & Dry & Wet \\
\hline 1 & Yms & 2.9 & 52.6 & 52.6 & 2.64 & 2.65 \\
\hline 2 & Yms & 3.5 & 50.5 & 50.3 & 2.64 & 2.65 \\
\hline 3 & $\mathrm{Ku}$ & 349 & 72.8 & 169 & 2.66 & 2.69 \\
\hline 4 & $\mathrm{Ku}$ & 258 & 217 & 310 & 2.65 & 2.67 \\
\hline 5 & Yms (?) & 1.9 & 118 & 117 & 2.67 & 2.68 \\
\hline 6 & Yms & 0.2 & n.d. & 0.1 & 2.58 & 2.59 \\
\hline 7 & $\mathrm{Mm}$ & 0.7 & 0.2 & 0.5 & 2.58 & 2.64 \\
\hline
\end{tabular}

The western margin of the area shown on map B (pl. 1) is marked by a gradient expressed by northtrending contours; this gradient is generated by lowdensity valley fill, which thickens westward, in juxtaposition with Proterozoic rocks intruded by plutonic rocks. The gradient is steepest in the southwestern part of the area where the Proterozoic rocks have been intruded by relatively dense gabbro. Farther north, the gradient decreases either because the Proterozoic rocks are intruded by less dense granodiorite or because the valley fill is thinner.

A broad gravity high $(\mathrm{H}$, map B, pl. 1) in the southeastern part of the map area plunges northwestward to the vicinity of Farlin Creek, indicating that relatively dense gabbro underlies a larger region than its outcrop indicates. This gravity high was previously known (Kaufmann and others, 1983), but its shape was uncertain because of a paucity of data. The new data show that the high is interrupted to the north by a pronounced indentation of the -218 -milligal contour. This indentation outlines a narrow gravity low (L, map B, pl. 1) that is inferred to mark a subsurface boundary between a terrane with gabbro to the south and one without gabbro to the north. The low is approximately aligned with Farlin Creek. Subsurface rock alteration or injection of lowdensity silicic material, if confined to a narrow zone underlying Farlin Creek, could be the source of the gravity low. However, there is no geologic or geochemical evidence of such a low-density body. 
Magnetic-Anomaly Data

The aeromagnetic anomaly map shown as map C (pl. 1) is part of a survey flown at a barometric elevation of $2,740 \mathrm{~m}$ (meters) and consisting of east-west flight lines spaced about $0.8 \mathrm{~km}$ (kilometers) apart (U.S. Geological Survey, 1979). Aeromagnetic values, contoured at a 20-gamma interval, are based on the International Geomagnetic Reference Field 1975, updated to the month and year flown, to which a bias of 57,270 gammas has been added. In addition to aeromagnetic data, ground magnetic data were obtained along traverses shown on map D (pl. 1). The ground magnetic data were measured by a proton-precession magnetometer mounted on a staff $3 \mathrm{~m}$ high. Profiles of both ground and aeromagnetic data along these traverses appear on figure 3 and show that the ground anomalies are greatly attenuated with altitude.

The steep magnetic gradient expressed by north- to northeast-trending contours across much of the central part of map C (pl. 1) follows exposed and partly buried contacts of magnetic plutonic rocks that intrude the less magnetic Proterozoic and Paleozoic sedimentary rocks. The circular high in the southeastern part of the map $C$ area is inferred to reflect highly magnetic gabbro at the margin of, and extending beneath, the exposed granodiorite, in agreement with the gravity-anomaly data. Like the gravity high in this region, the magnetic high is interrupted to the north by a pronounced indentation of contour lines in the form of a low in the vicinity of Farlin Creek. Confirmation of this low is supplied by ground magnetic profile $B-B^{\prime}$ although the profile does not correspond in position to the lowest part of the aeromagnetic low. The magnetic low in part results from the polarization effect caused by the highly magnetic gabbro to the south that is also topographically high, but, unlike the gravity low, the magnetic low extends over the block stream (unit $\mathrm{Qb}$, map A, pl. 1), and only parts of the two lows overlap. In addition to the polarization effect, the magnetic low is interpreted to be caused by a narrow zone of relatively nonmagnetic subsurface rock, part of which is also lower in density than surrounding rocks as interpreted from gravity-anomaly data. Magnetic profile $A-A^{\prime}$ (fig. 3) illustrates strikingly the low magnetic character of the Paleozoic sedimentary rocks and also the local variations in the magnetic field that are not evident in the aeromagnetic data.

\section{Conclusions}

The gravity- and magnetic-anomaly maps are remarkably consistent with one another inasmuch as each map shows (1) a conspicuous gradient near the margin of exposed or buried plutonic rocks, (2) a salient high over rock terrane inferred to be gabbro-rich beneath a tract of mapped granodiorite partly rimmed by gabbro at the surface, and (3) a narrow low shown by indented contours (although the gravity and magnetic lows are only partially coincident), aligned with Farlin Creek at the northern margin of the salient high, indicating a narrow zone of relatively low magnetization and density.

The only geophysical signatures of interest with regard to possible subsurface mineralization are the partially overlapping paired lows along Farlin Creek. These lows could be associated with rock alteration or silicic (lowdensity) intrusion in a narrow band beneath Farlin Creek; if so, the possibility of mineralization is enhanced. However, no significant alteration or silicification at the ground surface is indicated by geologic or geochemical data in this region.

\section{Electrical Studies}

In and adjacent to the Farlin Creek area, electrical properties were measured along 2 telluric traverses and at 10 audio-magnetotelluric (AMT) stations, located on map D (pl. 1) and described in more detail by Hoover and Pierce (1985). Abrupt decreases in telluric voltage, and hence resistivity, noted on the western ends of both profiles (fig. $4 A, 4 B$ ), result from thick alluvial fill in the valley on the west, and the position of the abrupt change is inferred to mark the location of a range-front fault.

The eastern half of traverse 1 is partly within the study area (map D, pl. 1). Resistivities measured between stations 0 and $1 \mathrm{E}$, corresponding to AMT sounding 63 (fig. 4D), are high, above $1,000 \mathrm{ohm}$ meters for frequencies below $100 \mathrm{hz}$ (hertz), which are those that measure the Earth's resistivity at depths greater than about $1 \mathrm{~km}$ $(0.6 \mathrm{mi})$. These values are typical of a relatively tight, unaltered intrusive rock, and the gradual increase in resistivity with decreasing frequency shows the gradual decrease in water-filled fractures with depth. Areas of low resistivities within the mapped granodiorite are located on traverse 1 near stations 5-6W and 3-4E (map D, pl. 1). These low resistivities are inferred to be related to increased fracturing and alteration of the granodiorite in the vicinity of these dipole positions. Resistivities implied by the telluric data at stations $3-4 \mathrm{E}$ are about $250 \mathrm{ohm}$ meters.

AMT soundings at station 65 (map D, pl. 1), which is $1,000 \mathrm{ft}$ south of dipole $5-6 \mathrm{~W}$ on telluric line 1 , show distinctly (fig. $4 F$ ) that a lateral resistivity boundary is present. This is probably the same boundary detected near station $5 \mathrm{~W}$ on the telluric line. No AMT sounding is close to dipole $3-4 \mathrm{E}$ on line 1 . Soundings at station 64 (fig. $4 E$ ), within the study area, show apparent resistivities of more than 2,000 ohm meters, and resistivities increase with depth. Soundings at station 62 (fig. $4 C$ ), on the eastern side of the study area, $1 \mathrm{mi}$ south of dipole $3-4 \mathrm{E}$, however, are significantly different. There, surface resistivities are high, but a zone of moderate apparent resis- 

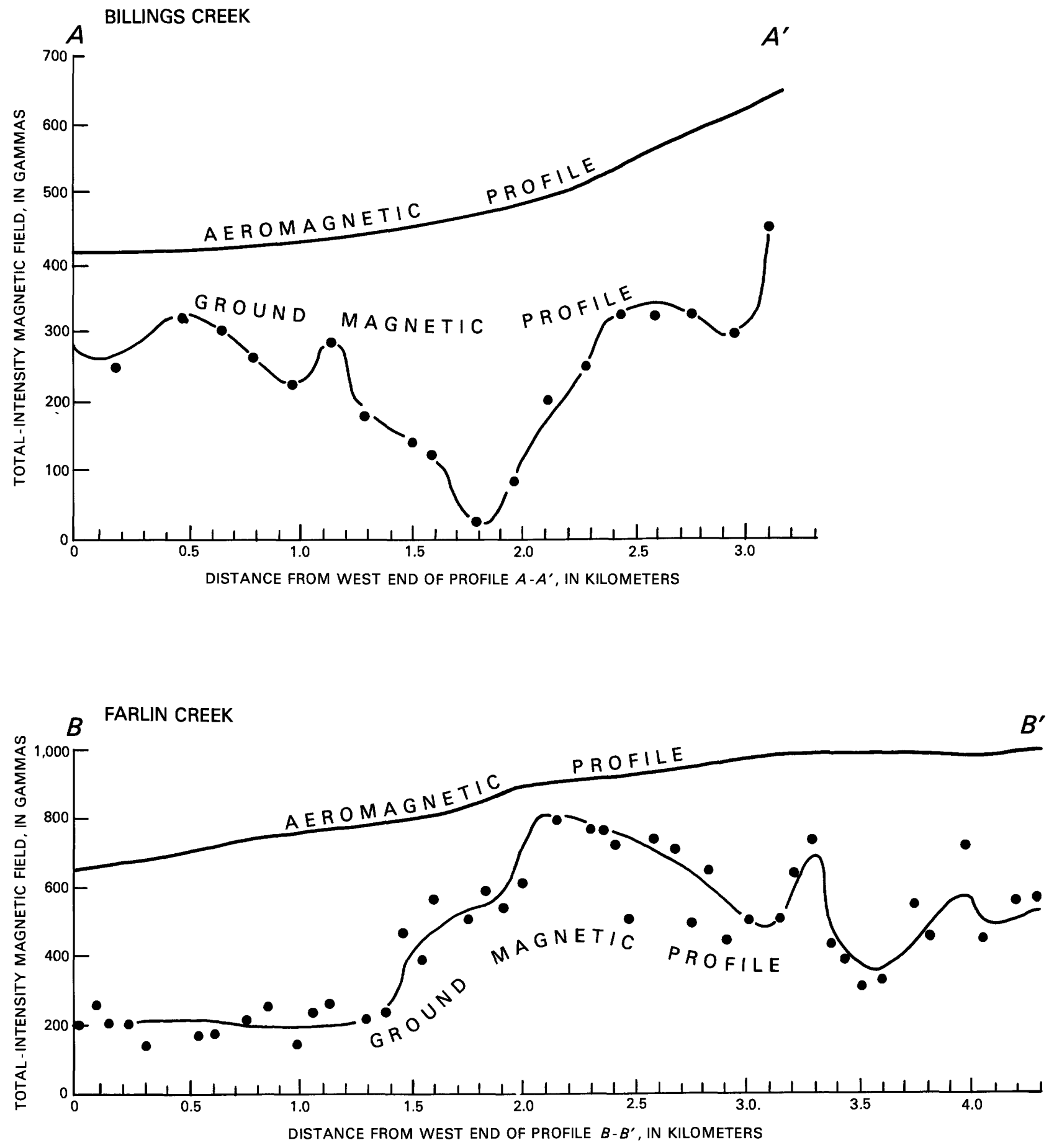

Figure 3. Total-intensity ground magnetic profiles $A-A^{\prime}$ and $B-B^{\prime}$, Farlin Creek Wilderness Study Area, Beaverhead County, Mont., shown in comparison with corresponding interpolated aeromagnetic profiles at a flight elevation of $2,740 \mathrm{~m}$. Note the conspicuous attenuation of short-wavelength anomalies with increasing height above ground. Horizontal scale and gamma values are relative to values assumed for points $A$ and $B$, respectively, at west ends of profiles. Dots represent readings at magnetometer stations.

tivities of about $300 \mathrm{ohm}$ meters was observed. The sounding curves are distorted by lateral effects, but a fit to these data using a one-dimensional model indicates a low-resistivity body of $200 \mathrm{ohm}$ meters at a depth of 700 $\mathrm{m}(2,300 \mathrm{ft})$; this body is interpreted as hydrothermally altered rock that could be mineralized with molybdenum.

Features of some of the mineralized areas in the south-central Pioneer Mountains tend to support this infer- 


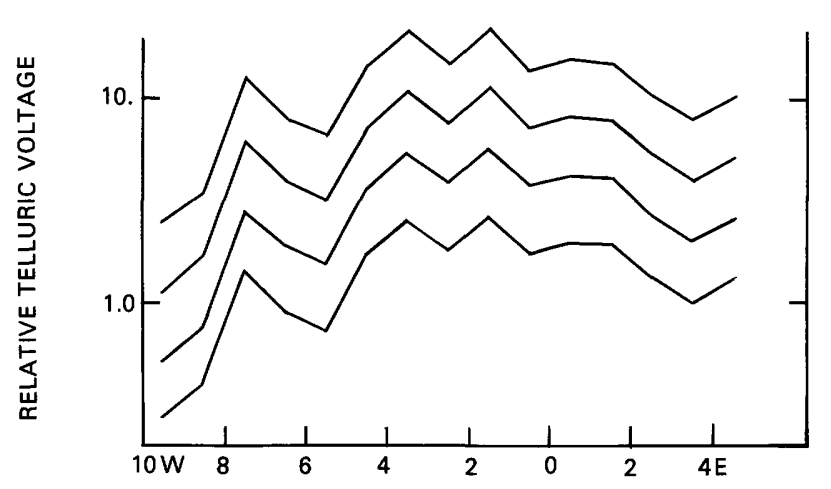

A Station Number
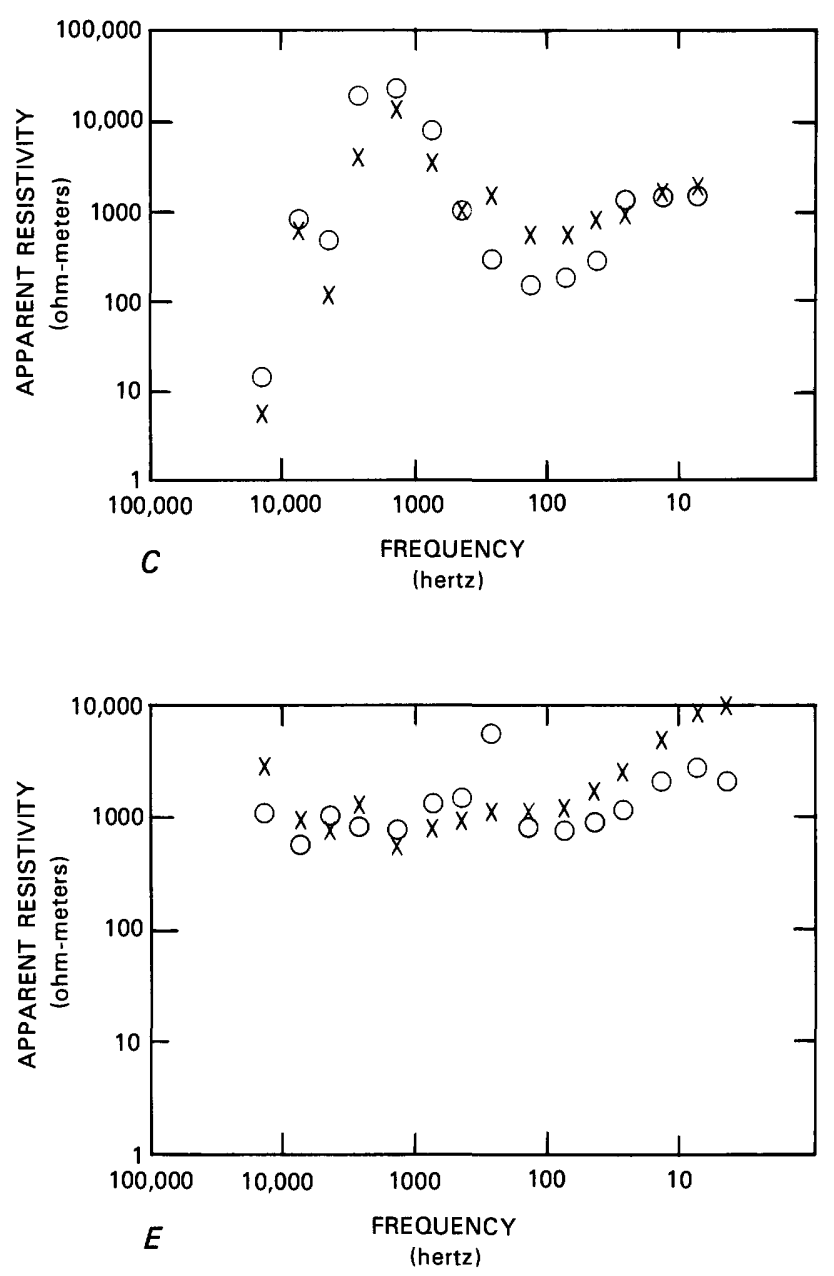
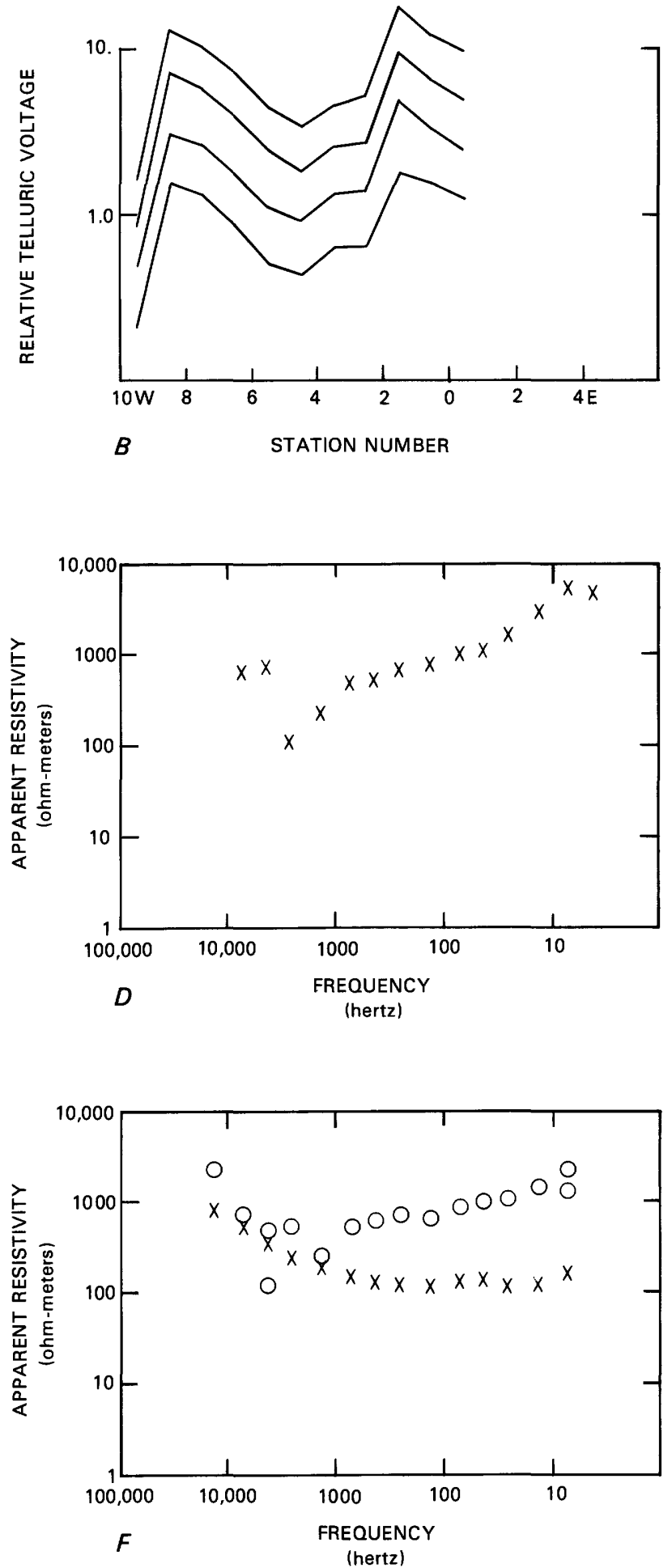

Figure 4. Graphs showing telluric voltage along telluric traverses and resistivities at AMT (audio-magnetotelluric) stations (map D), Farlin Creek Wilderness Study Area and vicinity, Beaverhead County, Mont. $A$, telluric traverse $1 ; B$, telluric traverse $2 ; C$, AMT station $62 ; D$, AMT station $63 ; E$, AMT station $64 ; F$, AMT station 65. O, north-south dipole; $X$, east-west dipole.

ence of a buried mineralized zone at Farlin Creek based on the electrical data. The observed resistivities within the granodiorite in the northeastern part of the study area are similar to those observed during an earlier investiga- tion of a molybdenum prospect $6 \mathrm{mi}$ to the north (D. B. Hoover, unpub. data, 1981). This prospect, the Price Creek altered zone of Pearson and Berger (1980), is also partly in Uphill Creek Granodiorite similar to that at Far- 
lin Creek, but at Price Creek the rock has been intensely altered at the surface. The contacts of altered rock with unaltered rock at Price Creek are commonly sharp. If a similar sharp contact exists at Farlin Creek, a buried altered zone may not be evident at the surface. The sounding at station 62 (fig. $4 C$ ) shows that the altered zone is below $500 \mathrm{~m}(1,640 \mathrm{ft})$. Inasmuch as vein and replacement deposits of base and precious metals are considered typical of lower temperature environments around large molybdenum systems, the Polaris district, less than $1 \mathrm{mi}$ north of the Farlin Creek area, and the Baldy Mountain district, about $2 \mathrm{mi}$ to the southeast, could possibly be distal products of such a system.

\section{Mineral and Energy Resources}

The eastern Pioneer Mountains contain several small to medium-sized mining districts (fig. 1), some of which were valuable for gold, others for silver and lead, and still others for tungsten; several molybdenum prospects and deposits are also known but have not been mined. The Farlin Creek area is between two of these districts, about $0.5 \mathrm{mi}$ south of the Polaris district and 1-4 mi north and northwest of the Baldy Mountain district. These two, like most other districts in the eastern Pioneer Mountains, have produced ores from Paleozoic carbonate rocks near or adjacent to the Pioneer batholith or to satellitic plutons. The Polaris district contains only one significant mine, the Polaris, from which silver-rich ore has been mined from quartz veins in dolomitic marble along and adjacent to a fault that separates the marble from Proterozoic quartzite (north of area shown on fig. 2). The Baldy Mountain district also contains quartz veins in carbonate rocks, but none of the numerous small mines that explored these veins has proved to be very productive. The small amounts of ore mined (Geach, 1972) were valuable mainly for gold. Tungsten in skarn is also known to be present in small amounts in the Baldy Mountain district, but production has been insignificant (Pattee, 1960).

The only mining district in the eastern Pioneer Mountains that has a geologic setting at all similar to the Farlin Creek area - that is, within the Pioneer batholithis the Elkhorn district, about 5-10 mi north of the Farlin Creek area. This district contains a large number of quartz veins, some of which have been mined, mainly for silver localized in the highly fractured hanging wall of a major through-going fault. No similar structure is known in the study area. The Elkhorn district, together with the nearby Price Creek altered zone, has been explored for molybdenum.

An examination of the granodiorite within the Farlin Creek area by the Bureau of Mines (Schmauch, 1985) failed to disclose evidence of mineralization, hydrothermal alteration, or significant fracturing. The only evidences of prospecting are near the north edge of the area where bulldozer cuts associated with claim posts evidently represent the perfunctory digging done in 1983 to validate claims staked in a solid block (Schmauch, 1985). No evidence of mineralized rock was found in these pits, only slightly weathered, brown granodiorite. Samples taken by the USBM and the USGS from these pits (tables 1 and 2) contained no detected gold or silver nor other elements in amounts that suggest that the rocks have been mineralized.

Electrical geophysical data show resistivities in two areas in the eastern part of the study area that are similar to values measured over the Price Creek molybdenum prospect a few miles to the north; these electrical anomalies may be caused by hydrothermally altered rock at depth. In addition, the partial overlap of magnetic and gravity lows in the central part of the area is another anomaly that could be caused by altered rock at depth. Although no evidence of alteration or mineralization was found at the surface, on the basis of the geophysical evidence these three areas are considered to have moderate mineral resource potential for molybdenum. The level of certainty of the assigned moderate potential is $\mathrm{B}$, which means that available data are sufficient only to suggest the level of potential (see definitions inside front cover).

The entire study area has low potential for all metals except molybdenum, at certainty level $\mathrm{C}$, which means that available information gives a good indication of the level of potential. The entire area has low potential for nonmetallic and energy minerals, oil and gas, and geothermal energy, at certainty level C.

\section{REFERENCES CITED}

Breit, G. N., 1980, Geochemical exploration study of the Polaris mining district and vicinity, Beaverhead County, Montana: Golden, Colorado School of Mines, M.S. thesis, 265 p.

Cordell, L. E., Keller, G. R., and Hildenbrand, T. G., 1982, Bouguer gravity map of the Rio Grande Rift, Colorado, New Mexico, and Texas: U.S. Geological Survey Geophysical Investigations Map GP-949, scale 1:1,000,000.

Corey, A. V., 1933, Some gold deposits of Broadwater, Beaverhead, Phillips, and Fergus Counties, Montana: Montana Bureau of Mines and Geology Memoir 10, 45 p.

Geach, R. D., 1972, Mines and mineral deposits (except fuels), Beaverhead County, Montana: Montana Bureau of Mines and Geology Bulletin 85, 193 p.

Goudarzi, G. H., compiler, 1984, Guide to preparation of mineral survey reports on public lands: U.S. Geological Survey Open-File Report 84-787, 51 p.

Hoover, D. B., and Pierce, H. A., 1985, Audio-magnetotelluric sounding and telluric traverse data release for the Farlin Creek Wilderness Study Area, Beaverhead County, Montana: U.S. Geological Survey Open-File Report 85-16, 26 p. 
Kaufmann, H. E., Sorenson, S. B., and O'Neill, K. J., 1983, Principal facts and complete Bouguer gravity anomaly map for the Dillon $1^{\circ} \times 2^{\circ}$ quadrangle, Montana and ldaho: U.S. Geological Survey Open-File Report 83-51, 75 p.

Pattee, E. C., 1960, Tungsten resources of Montana-Deposits in the Mount Torry batholith, Beaverhead County: U.S. Bureau of Mines Report of Investigation 5552, 41 p.

Pearson, R. C., and Berger, B. R., 1980, Geology and geochemistry of some hydrothermally altered rocks, Pioneer Mountains, Beaverhead County, Montana: U.S. Geological Survey Open-File Report 80-706, 24 p.

Pearson, R. C., Berger, B. R., Kaufmann, H. E., Hanna, W. F., and Zen, E-an, 1983, Mineral resources of the eastern Pioneer Mountains, Beaverhead County, Montana: U.S. Geological Survey Open-File Report 83-507, 51 p.

Pearson, R. C., and Zen, E-an, 1985, Geologic map of the eastern Pioneer Mountains, Beaverhead County, Montana: U.S. Geological Survey Map MF-1806-A, scale 1:50,000.
Schmauch, S. W., 1985, Mineral resources of the Farlin Creek study area, Beaverhead County, Montana: U.S. Bureau of Mines Mineral Land Assessment Open-File Report MLA$62-85,8 \mathrm{p}$.

Snee, L. W., 1978, Petrography, K-Ar ages, and field relations of the igneous rocks of part of the Pioneer batholith, southwestern Montana: Columbus, Ohio State University, M.S. thesis, $110 \mathrm{p}$.

1982, Emplacement and cooling of the Pioneer batholith, southwestern Montana: Columbus, Ohio State University, Ph.D. thesis, 320 p.

U.S. Bureau of Mines and U.S. Geological Survey, 1980, Principles of a resource/reserve classification for minerals: U.S. Geological Survey Circular 831, 5 p.

U.S. Geological Survey, 1979, Aeromagnetic map of the West Pioneer-Beaverhead area, Montana: U.S. Geological Survey Open-File Report 79-758, scale 1:250,000. 


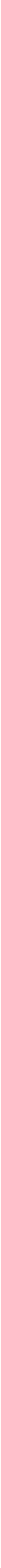


APPENDIX 


\title{
DEFINITION OF LEVELS OF MINERAL RESOURCE POTENTIAL AND CERTAINTY OF ASSESSMENT
}

\author{
Definitions of Mineral Resource Potential
}

LOW mineral resource potential is assigned to areas where geologic, geochemical, and geophysical characteristics define a geologic environment in which the existence of resources is unlikely. This broad category embraces areas with dispersed but insignificantly mineralized rock as well as areas with few or no indications of having been mineralized.

MODERATE mineral resource potential is assigned to areas where geologic, geochemical, and geophysical characteristics indicate a geologic environment favorable for resource occurrence, where interpretations of data indicate a reasonable likelihood of resource accumulation, and (or) where an application of mineral-deposit models indicates favorable ground for the specified type(s) of deposits.

HIGH mineral resource potential is assigned to areas where geologic, geochemical, and geophysical characteristics indicate a geologic environment favorable for resource occurrence, where interpretations of data indicate a high degree of likelihood for resource accumulation, where data support mineral-deposit models indicating presence of resources, and where evidence indicates that mineral concentration has taken place. Assignment of high resource potential to an area requires some positive knowledge that mineral-forming processes have been active in at least part of the area.

UNKNOWN mineral resource potential is assigned to areas where information is inadequate to assign low, moderate, or high levels of resource potential.

NO mineral resource potential is a category reserved for a specific type of resource in a well-defined area.

\section{Levels of Certainty}

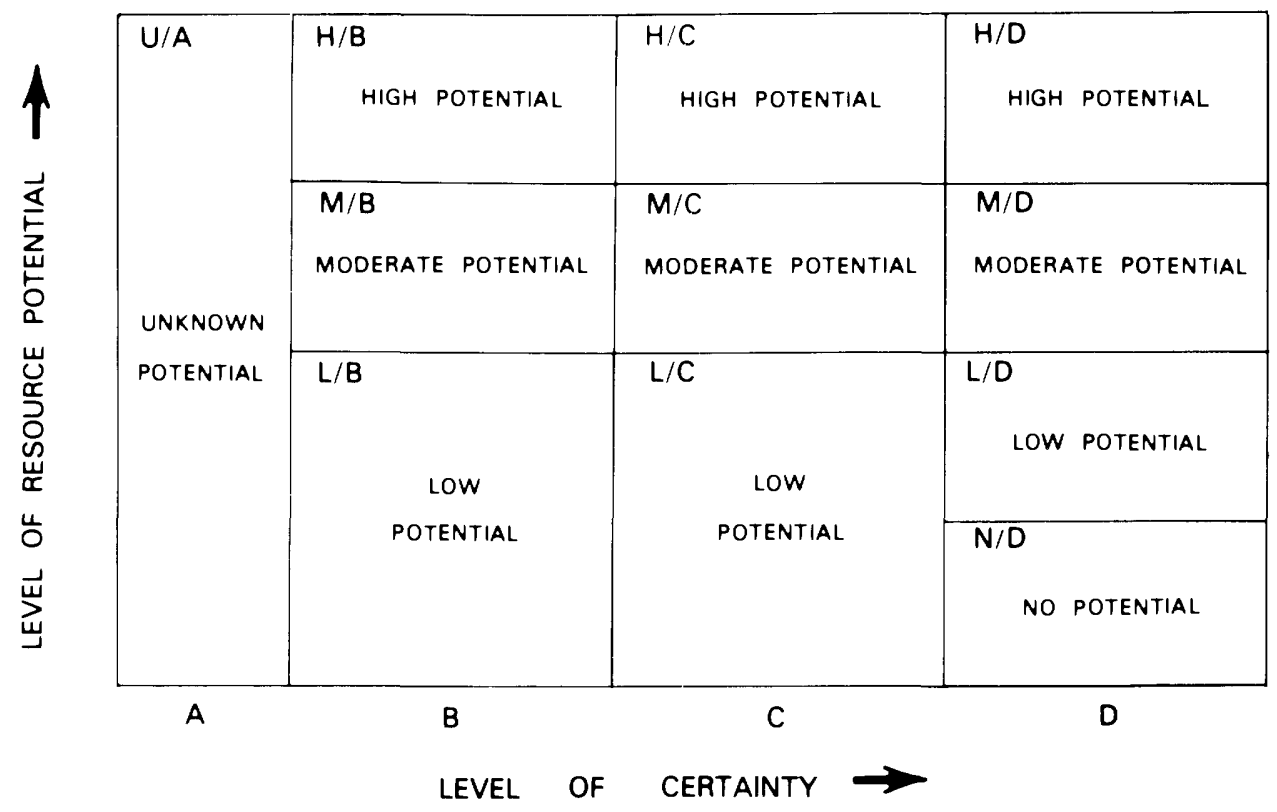

A. Available information is not adequate for determination of the level of mineral resource potential.

B. Available information suggests the level of mineral resource potential.

C. Available information gives a good indication of the level of mineral resource potential.

D. Available information clearly defines the level of mineral resource potential.

\section{Abstracted with minor modifications from:}

Taylor, R. B.. and Steven, T. A., 1983, Definition of mineral resource potential: Economic Geology, v. 78, no. 6, p. $1268-1270$.

Taylor, R. B., Stoneman, R. J., and Marsh, S. P., 1984, An assessment of the mineral resource potential of the San Isabel National Forest, south-central Colorado: U.S. Geological Survey Bulletin 1638, p. $40-42$.

Goudarzi, G. H., compiler, 1984, Guide to preparation of mineral survey reports on public lands: U.S. Geological Survey Open-File Report 84-0787, p. 7, 8. 
RESOURCE/RESERVE CLASSIFICATION

\begin{tabular}{|c|c|c|c|c|c|}
\hline & \multicolumn{3}{|c|}{ IDENTIFIED RESOURCES } & \multirow{2}{*}{\multicolumn{2}{|c|}{$\frac{\text { UNDISCOVERED RESOURCES }}{\text { Probability Rang̣e }}$}} \\
\hline & \multicolumn{2}{|c|}{ Demonstrated } & \multirow{2}{*}{ Inferred } & & \\
\hline & Measured & Indicated & & Hypothetical & Speculative \\
\hline ECONOMIC & Res & & Inferred Reserves & & \\
\hline $\begin{array}{l}\text { MARGINALLY } \\
\text { ECONOMIC }\end{array}$ & Margina & eserves & $\begin{array}{l}\text { Inferred } \\
\text { Marginal Reserves }\end{array}$ & & \\
\hline $\begin{array}{c}\text { SUB } \\
\text { ECONOMIC }\end{array}$ & $\begin{array}{r}\text { Dem } \\
\text { Subeconon }\end{array}$ & $\begin{array}{l}\text { strated } \\
\text { Resources }\end{array}$ & $\begin{array}{c}\overline{\text { Inferred }} \\
\text { Subeconomic } \\
\text { Resources }\end{array}$ & & \\
\hline
\end{tabular}

Major elements of mineral resource classification, excluding reserve base and inferred reserve base Modifued from U. S. Bureau of Mines and U. S. Geological Survey, 1980. Principles of a resource/reserve classificalion for minerals: U. S. Geological Survey Circular 831, p 5 
GEOLOGIC TIME CHART

Terms and boundary ages used in this report

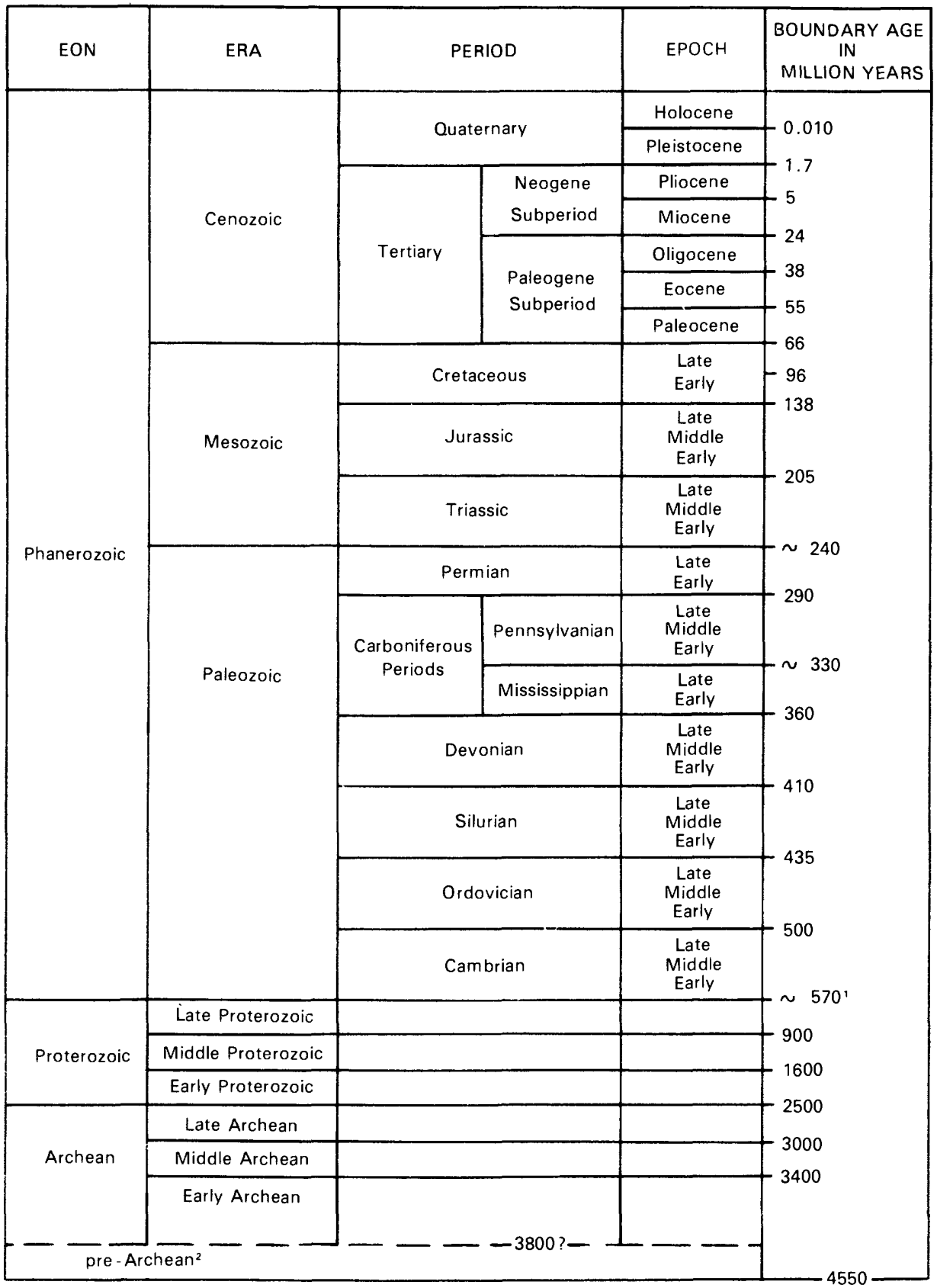

'Rocks older than $570 \mathrm{~m}$.y. also called Precambrian, a time term without specific rank.

${ }^{2}$ Informal time term without specific rank. 